\title{
Petrifying Earth Process: the stratigraphic imprint of key Earth System parameters in the Anthropocene
}

\author{
Jan Zalasiewicz ${ }^{1}$, Will Steffen ${ }^{2}$, Reinhold Leinfelder ${ }^{3}$, Mark Williams ${ }^{1}$ and Colin \\ Waters ${ }^{4}$.
}

1. Department of Geology, University of Leicester, University Road, Leicester LE1 7RH, UK.

2. The Australian National University, Canberra ACT 0200, Australia.

3. Department of Geological Sciences, Freie Universität Berlin, Malteserstr. 74100/D, 12249 Berlin, Germany.

4. British Geological Survey, Keyworth, Nottingham NG12 5GG, UK.

\begin{abstract}
The Anthropocene concept arose within the Earth System science (ESS) community, albeit explicitly as a geological (stratigraphical) time term. Its current analysis by the stratigraphical community, as a potential formal addition to the Geological Time Scale, necessitates comparison of the methodologies and patterns of enquiry of these two communities. One means of comparison is to consider some of the most widely used results of the ESS, the 'planetary boundaries' concept of Rockström et al. (2009) and the 'Great Acceleration' graphs of Steffen et al. $(2004,2007,2015 a)$, in terms of their stratigraphical expression. This expression varies from virtually non-existent (stratospheric ozone depletion) to pronounced and many-faceted (primary energy use) while in some cases stratigraphical proxies may help constrain anthropogenic process (atmospheric aerosol loading). The Anthopocene concepts of the ESS and stratigraphy emerge as complementary, and effective stratigraphic definition should facilitate wider transdisciplinary communication.
\end{abstract}

Keywords: Anthropocene, stratigraphy, Earth System science. 
The preservation of history is, we know, incomplete. Many events have taken place on this planet and left no trace of their passing. Many - but not all, for what traces remain are now the basis of the science of stratigraphy, the reconstruction of Earth history from rock strata. Since humans invented writing and drawing, the scope for preservation has increased, as historical archives have grown, that largely concerned the lives of our ancestors. In the last few decades, the scale of this preservation has grown enormously, and democratized extraordinarily, as the burgeoning electronic databases have come to capture many aspects of our lives..

Over these decades, too, our electronic recorders have looked beyond the crowded lives of our own species, to look at the planet itself. At many thousands of locations, temperature, $\mathrm{pH}$, wind speed, ocean chemistry, wave height, ice volume, soil activity and many more indicators of the planetary environment are continuously recorded by sensor and satellite. This is now the basis of Earth System science (ESS), a holistic discipline based on considering Earth as a single planetary-level complex system (Schellnhuber 1999; Lenton, 2016; Steffen et al., in prep.). The emerging narrative of this discipline, constructed and interrogated by a wide community of scientists, tells us that Earth is changing. It was the scale and speed of this captured planetary evolution that led, at a meeting in 2000 in Mexico, to Paul Crutzen's improvisation of the Anthropocene name and concept (Crutzen \& Stoermer 2000, Crutzen 2002).

The rest, of course, is history - itself now preserved in many forms for whatever might now count as posterity. This phenomenon is itself part of social history, with much to say about the speed of cross-disciplinary transfer of a new concept. The adoption of this concept by the social sciences and humanities reflects its power to articulate humanity's impact, leaving a lasting legacy on the planet. Its' holistic approach to considering diverse vectors of environmental change may have become appropriated as a symbolic term for our modification of the environment around us, to some extent diverging from the purely scientific definition at an isochronous boundary at a point where conceptually humans have come to drive planetary systems. But the history that was implicit in the 
new term was, from the beginning, of a much different scale of both time and of recording of Earth processes. While there is now debate about whether the Anthropocene should be regarded as a term of Earth history or of human history (Gibbard \& Walker 2014; Finney 2014; Finney \& Edwards 2016), there is no doubt that Crutzen placed it within geology and more specifically within stratigraphy. The Holocene, he said, had finished and a new interval of geological time had begun.

This concept was almost immediately adopted within the ESS community, where it was soon used as a central integrating concept (e.g. Steffen et al. 2004). The geological community responded more slowly, first with an initial analysis by a national commission, of the Geological Society of London (Zalasiewicz et al. 2008), then by an international working group of the International Commission on Stratigraphy, which is currently considering whether the Anthropocene should be formalized, or not, within the Geological Time Scale. It has no power of decision, but can collect and analyse the evidence, and make recommendations.

There is quite a difference between the research styles and philosophies of the communities that deal with formal stratigraphy and with ESS. The former have a long pedigree, taken back centuries to Charles Lyell, William Smith, Baron Cuvier and even earlier, while the latter is a relatively new discipline, just a few decades old. The former are focused on the classification of rock and of geological time from an Earth perspective, based upon relative superposition of strata rather than absolute ages, which have only been reliably determined in recent decades. The latter are primarily concerned with researching the modes and mechanisms of Earth System change. The former are overwhelmingly concerned with ancient, pre-human rock and time, while the latter have, as a strong central focus, the analysis and understanding of contemporary global change.

The extent to which these two major branches of study do or do not concur on the question of the Anthropocene may seem at first glance to be primarily a matter for the physical sciences. However, given the degree to which the Anthropocene has travelled widely across disciplinary boundaries and has been 
variously interpreted, it seems to us that the degree of convergence, or alternatively conflict, of view between the two disciplines most directly involved with the physical basis for the Anthropocene - as we explore below - should be of significance to those disciplines concerned with wider social and cultural aspects.

The distinction between ESS and stratigraphy as outlined above is of course in part a caricature - increasingly, stratigraphy has evolved towards understanding past global change through proxy evidence, and indeed ESS at least partly originates from the development of these methodologies, such as cyclic stratigraphy or sequence stratigraphy, which are derived from a systemic approach - trying to decipher sea-level change from patterns of ancient marine and coastal sedimentary deposits, and once the sea level curve has been established, to forecast (or, rather, in an Earth History setting, retrocast) sedimentation patterns, based on time- and space-bound sedimentation models. Interestingly, such a fusion of system analysis and stratigraphy was triggered by an economic, hence, societal framing - the search for fossil hydrocarbons using seismic methods (Haq et al. 1987, Wilgus et al. 1988, Catuneanu 2006).

Nevertheless, there is difference between the two communities, that may be symbolized by the rapid adoption of the Anthropocene concept by the ESS community (e.g. Steffen et al. 2004) by contrast with the more cautious and skeptical approach shown among the formal stratigraphic community (e.g. Finney, 2014; Finney \& Edwards 2016; Walker et al. 2015). To our knowledge the Anthropocene Working Group is the first such body tasked with investigating stratigraphic boundary definition to include an Earth System scientist among its membership, thus providing the potential for quantifying the scales of environmental change which should ultimately leave their signature in the geological record.

Therefore to square this particular circle - that is, to see whether the Anthropocene might formally become the epoch that Crutzen suggested, there is needed analysis of its material character, assessing characteristic 'fingerprints' of 
Anthropocene strata as well as considering trajectories in Earth surface processes. Such analysis has been a central focus of the initial study by the Stratigraphy Commission of the Geological Society of London (Zalasiewicz et al. 2008) and subsequently by the Anthropocene Working Group and its publications (Williams et al. 2011; Waters et al. 2014; Waters et al. 2016), where this concept is not just potentially a time unit (an Epoch) but a material 'timerock' unit of formal chronostratigraphy (that would be an Anthropocene Series: Zalasiewicz et al. 2014a).

So far, this particular exercise has mainly been rock-focussed: that is, looking to see what kind of signals are captured by the sedimentary strata, and then assessing their significance for characterizing and correlating these strata around the world. There is a wide array of these (Waters et al. 2016), including novel minerals and materials, geochemical signals reflecting industrial development, changing atmospheric composition in response to combustion of fossil fuels and evidence of biotic change. But their significance for stratigraphy has more to do with this geological utility than it has for gauging the importance of change to the Earth System. Hence, the artificial radionuclides scattered around the Earth may be regarded as a primary, and arguably the primary, marker for Anthropocene strata because of their global distribution, relatively easy detectability and near-synchroneity of expression, which broadly coincides with multiple signals of significant environmental change during the mid-20 $0^{\text {th }}$ century (Zalasiewicz et al. 2014a; Waters et al. 2015). However, by comparison with the scale of some other kinds of anthropogenic perturbation they may be regarded as environmentally trivial, even if one factors in the two devastating explosions at Hiroshima and Nagasaki.

This is not unusual in stratigraphy - many key chronostratigraphical boundary markers reflect events of slight environmental impact in themselves, although the boundaries themselves commonly reflect more profound surrounding changes. For example, the Ordovician-Silurian boundary event selected is defined by the appearance and wide distribution of a couple of distinctive graptolite species, an environmentally negligible event when compared with the 
major Earth System changes taking place around this level- a major warming event, marked deglacial sea level rise associated with increased marine anoxia, and mass extinction events (e.g. Zalasiewicz \& Williams 2014).

So, one might use this essay to turn this approach on its head. Rather than take the stratigraphic signals and ask if they correspond to environmentally significant events, one may take the environmental trends picked out as of major significance to contemporary global change by the ESS community and consider whether or not they will leave a recognizable signal within strata that may then be used as a basis to create chronostratigraphical units. Not everything can be fossilized. The use of radio waves or microwaves for television and radio to connect civilization is likely to leave absolutely no physical record on Earth, apart from the TV and radio receivers (though it may leave a kind of record in space indefinitely, as the energy of the various waves spreads out).

Nevertheless, sedimentary strata (including snow and ice layers) are sensitive recorders of many environmental processes. In sediments this may be through their inorganic mineral composition, or their biological content, or in ice through the preservation of ancient atmospheric chemistry and particulates, and so the range of proxy environmental indicators recognized is very large (IPCC 2013; Zalasiewicz \& Williams 2016), and growing. Hence, it is commonly feasible to compare the history captured by human observations with the history recorded in sediment layers (e.g. Haywood et al. 2013). One must, though, have good age constraint, and one must allow for the biases present in the stratigraphical record: for instance, hard-shelled organisms are better represented in strata than soft-bodied ones, and marine organisms have on the whole a better preservation potential than terrestrial ones. More subtly, one may relate patterns of the dispersal of marine waste materials to the sedimentary record of plastics and other materials, though the evolution of different controlling factors (e.g. changes from disposal in landfill to burning, or new recycling strategies) may be very difficult to glean from the stratigraphical record. 
Behind this relation stand the hypotheses as originally expressed or implied by Crutzen (2002), that humans have become a geological factor by their activities, and that these activities change the Earth System state and functioning. The resulting geological implications are that these changes are expressed as geological signals in the sediments now accumulating, and that these signals will persist throughout geologically significant time intervals, so there is no way back to the Holocene.

To examine these hypotheses and their implications, one might consider two major syntheses of ESS process: the nine 'planetary boundaries' proposed by Rockström et al. (2009), which represent thresholds in major planetary processes used to help define a 'safe operating space for humanity', and the trends represented in the now-iconic graphs of the post-WWII 'Great Acceleration' of Steffen et al. $(2004 ; 2007 ; 2015 a)$. The former are recorded as key indicators of long-term planetary habitability - by humans, at least, while the latter collectively build a picture of rapid and profound change to Earth surface processes, or, in from the perspective of ESS, to the structure and functioning of the Earth System. In the following section, these two syntheses are discussed, in particular in the context of the potential alignment of the modifications to the Earth System to the multiple environmental signals proposed to indicate the transition to an "Anthropocene state".

\section{Rockström et al. (2009)}

Climate change: this parameter is regarded as already beyond a 'safe operating space' (Rockström et al. 2009, Fig. 1; updated in Steffen et al. 2015b, Fig. 3). Given the importance of climate to geological process, it is small wonder that sophisticated methods to measure a range of components of climate change, including local temperature, ice volume (itself a proxy for global temperature), atmospheric carbon dioxide levels, humidity and sea level, from stratal properties have been devised (IPCC 2013; Zalasiewicz \& Williams 2016). Applied to the Anthropocene, these suggest that climate drivers such as atmospheric carbon dioxide and methane levels are now outside not only 
Holocene but also Quaternary norms, with concomitant increase of radiative forcing. However, global temperatures, though rising, are not yet in equilibrium and have yet to exceed peak interglacial temperatures, although they are now outside of the natural envelope of variability expected from astronomical forcing at this point in the current interglacial interval (Waters et al. 2016 and references therein).

Ocean acidification: the importance of this phenomenon in contemporary global change was recognized surprisingly late (Caldeira \& Wickett 2003), and this spurred considerable research into both modern and ancient acidification processes. Considerable progress has been made in understanding 'fossil' examples of ocean acidification such as the Paleocene-Eocene Thermal Maximum that occurred 55 million years ago. This was associated with the release of a large amount of carbon (as some combination of carbon dioxide and methane) from stores in the ground into the ocean/atmosphere system. It caused dissolution of deep sea carbonate floors evident in sedimentary successions that helped buffer the extra acidity (e.g. Zeebe and Zachos 2007). As with global climate, the main effects of ongoing change in this parameter still lie in the future - probably within decades rather than centuries at current rates of carbon emissions (Orr et al. 2005), although coral reefs and calcareous nannoplankton already seem to suffer in certain areas (cf. Hoegh-Guldberg et al. 2008, Doney et al. 2009). These hence would become "petrified" as leached skeletons already in the lowermost strata of the Anthropocene.

Stratospheric ozone depletion: This, the major anthropogenic change most closely associated with Paul Crutzen, the destruction of the polar ozone layer by chlorofluorocarbons (CFCs), seems not to have left any detectable signal in strata.

Nitrogen and phosphorus cycle perturbations: In both these cases, there has been a rough doubling of the amount of the reactive element at the terrestrial surface, in the case of nitrogen via fixing from the air by the Haber-Bosch process, and in the case of phosphorus by extraction from fossil-based 
concentrations in the ground (Filippelli 2002). Rockström et al. suggest that, by comparison with long-term background levels, the nitrogen cycle is already outside its planetary boundary, while that of phosphorus is just within. The Steffen et al. 2015b update assesses that phosphorus, too, is now outside of its boundary. Geological comparison via proxy evidence is more difficult, as elemental concentrations of $\mathrm{N}$ and $\mathrm{P}$ in strata tend to reflect local conditions. However, the analysis of Canfield et al. (2010) suggested that the Anthropocene perturbation to the nitrogen cycle is the greatest since the early Proterozoic, $\sim 2.5$ billion years ago, while clear changes to patterns of nitrogen isotopes in strata laid down in northern lakes, far distant from centres of population, have been used to identify an Anthropocene beginning at 1950 AD (Holtgrieve et al. 2011; Wolfe et al. 2013). More indirectly, over-fertilization of coastal seas is creating extensive 'dead zones' (Diaz \& Rosenberg 2004) through seasonal anoxia and mass die-off of macrobenthos. The sedimentary layers so created resemble those in the ancient geological record associated with reduced oxygen levels at the sea floor; however, the interpretation of such ancient strata is commonly ambiguous as to whether the low oxygen levels are the result of raised primary productivity of plankton (as in the modern dead zones) or reduced marine circulation.

Global freshwater use: this parameter (still within the planetary boundary according to Rockström et al.) is more difficult to gauge from the fossil record. In truth, with a few exceptions such as dam-building beavers (Kramer et al. 2012), no other organism has re-engineered major waterways or pumped large volumes of water from out of the ground (that is, from below the level where plant roots draw out water through transpiration). Nevertheless, in general terms human engineering of waterways has been described as a 'third major phase' of fluvial evolution in Earth history (Williams et al. 2014), following the transition from Archean fluvial sediments with 'reduced detrital' minerals by 2.4 billion years ago to the evolution of an oxygenated atmosphere and the development of a distinct mineralogical assemblage in subsequent river deposits in the early Proterozoic Eon, and the changes in river patterns associated with 
the spread of terrestrial vegetation in the Devonian and Carboniferous periods, $\sim 400$ to $\sim 350$ million years ago.

Change in land use: The tracking of change in land use during the Holocene and into the (putative) Anthropocene has been a major research area involving a variety of disciplines, notably archaeology and environmental geography, using a multitude of proxies (e.g. soil type, pollen, artefacts, bones) and augmented by modeling. The diachronous spread of anthropogenic land-use change over millennia has been increasingly well constrained (e.g. Ellis 2011, Ellis et al. 2012) and used in discussion of both possible wider impacts such as on climate and of the 'early' beginnings of the Anthropocene (Ruddiman 2003; Ruddiman et al. 2015). But it is this gradual nature of land-use change, notably through the migration of new agricultural technologies, that makes this such a poor potential indicator for the commencement of an isochronous Anthropocene epoch. Comparison with pre-Holocene terrestrial strata has been made as regards the progressive extinction of many megafaunal species (Koch \& Barnosky 2007) probably mostly by hunting 'overkill' by humans - with consequent impact on vegetation and perhaps even on regional climate (e.g. Doughty 2013). In earlier, pre-human geology, there are few direct analogues for human land use changes, though some proxies (e.g charcoal for forest fires (Scott \& Glasspool 2006; fungal spore 'spikes' for more extensive terrestrial devastation: Vajda \& McLoughlin 2004) may be regarded as comparisons. The biological element associated with land use changes, in creating engineered monocultures to sustain a single species, has no analogue in past geology and has been suggested to represent a major step change in biospheric evolution (Williams et al. 2015).

\section{Biodiversity loss (now changed to "Change in biosphere integrity", Steffen}

et al. 2015b): This planetary boundary, regarded by Rockström et al. as already exceeded, has inspired a good deal of effort to gain meaningful comparison with past extinction events. There are considerable difficulties involved, not least the uncertainties regarding current species numbers (Mora et al. 2011) and inherent biases involved in fossilization towards hard-shelled or otherwise skeletonized marine organisms. Nevertheless, at least within certain categories, comparisons 
may sensibly be made (Kidwell 2015), and the kind of large-scale syntheses made by Barnosky et al. (2011, 2014; see also Ceballos et al. 2015, Pimm et al. 2014) suggest considerable elevation of extinction rates that, with current trajectories suggest a geologically imminent (2-3 centuries) mass extinction event on a par with the 'Big Five' extinction events of the Phanerozoic Eon. Currently, the geologically unprecedented level of species invasions is arguably producing a larger biostratigraphical signal than are extinctions per se, and both together are in effect redirecting the course of Earth's biological (and hence future palaeontological) evolution. There are also striking changes in the composition of biological assemblages. Smil (2011) estimated that humans now make up of the order of one-third by mass of large land vertebrates, with most of the other two-thirds being the vertebrates that we keep to eat (cows, pigs, sheep and so on). Wild vertebrates likely now make up something less than $5 \%$ of the present-day total. This might be compared with the situation before human impact, when biomass was divided among 350 large land vertebrate species (Barnosky 2008), a species number that was roughly halved during the megafaunal extinctions in late Pleistocene to Holocene times (Koch \& Barnosky 2006) and continues to decline today (Ceballos et al. 2015). A more subtle, but equally striking signal is the estimated order-of-magnitude increase of large vertebrate biomass from an inferred pre-human baseline to the present day (Barnosky 2008). This is largely a function of the directed increase in primary productivity through the 'extra' N, P and other nutrients that supply fodder and forage (with energy input from fossil fuels), and then the feeding of this to the domestic animals that we in turn then eat. These are major signals. However, the inherent diachroneity in species changes through extinction, invasive spread or assemblage change across the planet makes biostratigraphy, the preferred choice for definition of most deep-time geological units, largely unsuitable for such a geologically young unit as the Anthropocene.

Atmospheric aerosol loading: This is one of two parameters (see also below) that to Rockström et al. are currently 'not quantified', although the 2015 update has assessed that aerosol loading in the South Asian monsoon region is now beyond its regional boundary and is approaching a high risk zone. One aspect of 
this that is amenable to stratigraphical analysis is the dissemination and subsequent sedimentation of fly ash particles from the high-temperature combustion of hydrocarbons, both as inorganic particles (measurable in sediments such as peats by magnetic analysis) and as spherical carbonaceous particles (that may be recovered by means akin to those used by palaeontologists studying fossil pollen). Analogous naturally-formed particles have been used to, for instance, help characterise the Cretaceous-Tertiary boundary level (Harvey et al. 2008). Studies carried out to date on recent sediments (Oldfield 2015; Rose 2015; Swindles et al. 2015) have been used to help suggest a mid-20 th century boundary for the Anthropocene (see also Waters et al. 2016). Sulfate aerosols derived from fossil fuel combustion show a prominent rise and peak in glacial ice during the second half of the $20^{\text {th }}$ century, but are less distinctive of the Anthropocene, in that comparable sulfate spikes can be caused by volcanic eruptions.

Chemical pollution (now “Novel entities”, Steffen et al. 2015b): This other 'unquantified' parameter represents a wide spectrum of chemicals, many novel, that have been disseminated in the environment by human action. While comprehensive stratigraphic assessment is also premature, a number of signals may be discerned and compared with signals in older strata. There are chemical novelties, specifically long-lasting persistent organic pollutants (POPs) that include a number of pesticides, that have been shown to be characterize postmid-20th century strata (Muir and Rose, 2007; Paull et al. 2006) and that might prove to be as persistent as the long-chain haptophyte algal-derived alkanes used as palaeotemperature proxies in strata millions of years old (Lawrence et al. 2007). Radioactive pollution, too, represents a specific marker (Waters et al. 2015 ) though one that will decay away in $\sim 100,000$ years (with respect to plutonium-235, the longest-lived of the common artificial radionuclides); the resultant pattern of daughter isotopes, though more subtle, may in the far future betray the mark of atomic fission. As mentioned earlier, atmospheric fallout from nuclear testing has considerable advantages as a potential tool for marking the start of the Anthropocene. This has led to the proposal that this putative time interval could coincide with the start of the atomic age with the first detonation 
of the Trinity nuclear device in New Mexico, at the specific date of 16 July 1945 (Zalasiewicz et al., 2015). But it was not until 1952, with the much larger thermonuclear detonations, that the fallout became globally dispersed on land, in oceans and in glacial ice (Waters et al., 2015).

Other forms of pollution include metals, particularly toxic heavy metals such as cadmium, lead and mercury. These are in effect selectively eroded and brought to the surface by humans, often from great depths in the crust, with a fraction lost in the extraction and manufacturing process and disseminated as metal-rich plumes through soils and river sediments, often ultimately enriching lacustrine and coastal sediments downstream. The recognition and assessment of such enhanced metal contents needs rigorous analysis of the range of 'natural' background levels, but reveals widespread significant enrichments around mining and industrial centres (e.g. Gałuszka et al. 2014). One might here make analogies with ancient examples of metal enrichment in surface sediments during some ore-forming processes, particularly in weathering-enriched 'gossans' and, more intriguingly, with rare, ancient metal-enriched marine strata such as the Kupferschiefer, a naturally metal-rich stratum of late Permian age still worked as a major ore in central Europe. It is still a matter of speculation whether humans are now creating modern Kupferschiefers in some parts of the world.

\section{The 'Great Acceleration' graphs}

These graphs were first published by Steffen et al. in 2004, and subsequently republished in 2007 as supporting evidence for the 'Great Acceleration', and revised, modified and updated in 2015a. The aim "was to record the trajectory of the 'human enterprise' through a number of indicators and, over the same time frame, track the trajectory of key indicators of the structure and functioning of the Earth System" (Steffen et al., 2015a). They compiled data from diverse sources and examined global trends dating back to the mid-18 ${ }^{\text {th }}$ century in 24 
parameters, divided equally into 'socio-economic trends' and 'Earth System trends'. Most of these clearly showed the marked upswing that, beginning 1950 CE, collectively makes up the 'Great Acceleration'. By and large, they are more detailed in scope than the 'planetary boundaries' of Rockström et al. (2009), although a few, such as water use, are in effect identical.

\section{Socio-economic trends in Steffen et al (2015a):}

- Population (there is also Urban population as a separate graph, showing a similar but steeper upwards trend). Rapid growth of human population, closely linked with increased consumption of resources, along with accelerated technological development, represent the three driving forces for many of the anthropogenic signatures that are considered indicative of the Anthropocene (Waters et al. 2016). But it is also a fundamental driver for most, if not all, of the socio-economic and Earth System trends.

However, tracking the growth in human numbers from their preserved remains as a direct biostratigraphic signal, and comparing it with that of other large vertebrates present and past, presents a unique palaeontological challenge (from a far future perspective), given that we are the only species with such sophisticated and varied means of disposing of our own remains, notably with various forms of burial and cremation. The biases of preservation involved are different from the factors (termed taphonomic factors) that affect the preservation of modern and fossil animal carcasses in more or less natural circumstances (e.g. Behrensmeyer 2001) and are different from those of the animals that we eat (the butchered bones of which turn up in large amounts in landfill sites).

Two financial trends (Real GDP and Foreign Direct Investment) are not in any meaningful sense directly preservable stratigraphically (other than in the sporadic preservation of coins, that would not offer meaningful information on trends, but is of importance geologically as a technofossil with imprinted age of manufacture), nor do they have any sensible analogue in animal communities 
prior to those of culturally modern humans. Money is clearly a hugely significant driver, amplifier and modulator of geological process today and deserves study in that light. But, its activity - particularly now that much finance is 'virtual' and created and transferred electronically - will not leave direct stratal traces.

Primary energy use, being currently largely hydrocarbon-based, leaves a clear, permanent stratigraphic trace through such proxies as changes in carbon isotopes, fly ash and black carbon residues and in increased atmospheric carbon dioxide, directly measurable in ice cores and, with more difficulty, using proxies such as $\mathrm{Ca} / \mathrm{Mg}$ ratios and fossilized plant stomata in older successions (Waters et al. 2016, Zalasiewicz \& Williams 2016, and references therein). Other energy sources (e.g. hydropower - which in the Steffen et al. schemes has a separate trend of Large Dams - solar and tidal power) may locally leave preservable infrastructure, some accompanied by modified sediment patterns such as sediment accumulating behind dams), but will be much less easily interpretable into any kind of global picture. Nuclear power leaves long-lasting residues with geological antecedents (the Oklo natural reactors, see above) though globally these are mostly overprinted by bomb-produced radionuclides, which may not fit all definitions of energy production.

Water use is effectively the same parameter as that used by Rockström et al., and considered above.

Paper production is an intriguing parameter. The amounts noted - rising from $\sim 50$ million tons annually in the mid-20 th century to $\sim 400$ million tons annually today, is broadly comparable to that for plastics (Waters et al. 2016; Zalasiewicz et al. 2016) - hence, about enough has been produced to wrap the whole world in a sheet of paper. While paper is much less inert than plastic, especially in the aqueous realm, and can decompose, and be burnt or recycled, its preservation potential when buried in landfill sites is surprisingly high, perhaps in part due to the chemical processes associated with bleaching, fillers, coating and printing (Rathje \& Murphy 1992). In general, paper may be expected to fossilize, in 
appropriate geological settings, about as well as delicate plant fossils such as leaves - and fossil leaves are not uncommon in the stratigraphic record.

Transportation and International tourism, like finance, are very important agents of geological change, directly and indirectly, but the stratigraphic evidence left is likely to be fragmentary. Direct evidence may take the form of the transporting hardware - cars, trains, ships, aeroplanes - though, shipwrecks apart, these are among the more consistently recycled of the technofossils that humans make. On land, roads may locally be preservable, though long-term these will typically appear as very short disconnected segments, and will be hard to reconstruct into anything like the original networks (see discussion in Zalasiewicz, 2008, pp. 231-2), although underground lines of communication such as tunnels have greater preservation potential (Zalasiewicz et al. 2014b). For air transport, almost no trace will remain of the pathways taken. Shipping, though, is leaving a trace beyond that of occasional wrecks. The coal-fired steamers of the nineteenth century left underwater 'trackways' of the clinker from coal-burning, tossed overboard (Ramirez-Llodra et al. 2011) while major shipping lines of all ages will show concentrations of rubbish in the sea floor sediments; these commonly have good preservation potential. More generally, transportation has carried distinctive solid materials (e.g. ornamental rocks for buildings), the patterns of transport of which can sometimes be gleaned where these have identifiable source areas, akin (though more complex) to the way that glacial transport paths can be reconstructed from trains of glacial erratics. Transportation has carried animals and plants too; the patterns of the very many invasive species constitute a striking, if complex, proxy record both on land and (especially from the use of ballast water) in the sea.

\section{Earth System trends of Steffen et al. (2015a)}

Several of these are trends in atmospheric gases; of those only stratospheric ozone (discussed above) leaves no discernable stratigraphic trace. Carbon dioxide, methane and nitrous oxide have all been recorded from polar ice 
(Waters et al. 2016 and references therein) and so the scale of Anthropocene perturbation from a Quaternary baseline (of the last 800,000 years, as far back as the records go) is clear. With $\mathrm{CO}_{2}$, some proxy evidence from earlier strata is present (see above), as for ocean acidification (also discussed above). This is not the case for the other two trace gases, though inferences have been made, say, of how methane levels might have related to the oxygenation of the atmosphere around the Archean/Proterozoic boundary (Zalasiewicz \& Williams 2012, pp. 28-30).

Of the marine trends, nitrogen to the coastal zone has already been discussed above. The stratigraphic impact of the substantial marine fish capture trend includes the physical reorganization of large parts of the continental shelf sea floor by trawling (Gattuso et al. 2009) a process moving into deeper water to affect parts of the continental slope and submarine canyons (Puig et al. 2012; Martin et al. 2015). The transformation of the trophic webs of the oceans will undoubtedly leave stratigraphic traces, but to our knowledge there has been little investigation of these as yet; fish fossils are not commonly used as routine

stratigraphic indicators and so ancillary effects on smaller plankton will need to be considered. Shrimp aquaculture is associated with widespread removal of coastal mangrove swamps that in turn has considerable effects on coastal sedimentation patterns. Again, systematic study as regards the resultant stratigraphic patterns have not yet been undertaken, to our knowledge.

\section{Discussion}

It is clear, from this brief general comparison, that there is a strong, but often indirect relationship between the kind of parameters analysed in studies of the contemporary Earth System, and the kind of signals, imprinted into layers of accumulating sediment, that are used in characterising and defining geological time units. 
A general relationship may be suspected from the outset, because fundamental changes to the Earth System will have pervasive effects upon the physical structure and chemical and biotic composition of our planet's surface, and that will lead to a greater chance of producing recognizable and correlatable stratigraphic signals.

Nevertheless, there are differences in scale and expression that may be explored. For instance, within the biological realm, there is some focus in Earth System studies on the higher trophic levels (as in the studies on marine fisheries) and on the fundamental structure of the changes. For stratigraphy, it is the small, ubiquitous organisms (foraminifera, molluscs, dinoflagellates, nannoplankton) that are more important, and within that specific events are sought - such as the appearance or extinction of a particularly widespread and distinctive species that can then be exploited as a time marker. Hence the accent in biostratigraphy in general, that in theory has many millions of fossil species at its disposal, for a small selected subset of these that form indicators of the fossil zones ('biozones') used by palaeontologists as time markers of strata.

Such specificity may have its advantages that might indeed be of wider use. For instance, in the two 'unquantified' parameters of Rockström et al., chemical pollution and atmospheric loading, it may be that the 'stratigraphic proxy' approach may help provide some means of quantification. Conversely, there would be merit in considering some of the Earth System trends, particularly novel ones such as aquaculture, and establishing not only the environmental effects of these practices, but also the stratigraphic ones. Such analysis may provide a different, and longer-term, perspective that may have its own value in informing policy.

Other trends, such as those associated with finance and patterns of economic practice, even though they likely produce little that may be regarded as a direct stratigraphic signal, are eminently worth investigating for their impact on Earth System processes, as variations in their operation certainly act to strongly 
amplify, diminish or otherwise modulate key Earth System characters such as carbon emissions and forest cover.

It is clear that comparison of these different perspectives on global change helps in understanding - as far as that is possible - of the whole. The Earth, we know, is complex - almost certainly the most complex planet in this solar system. The human factor in the Anthropocene is undoubtedly increasing its complexity in many ways but decreasing it in others, and the pattern and speed of its evolution. Such combined approaches to study give us the best chance of understanding what is currently happening on Earth.

\section{Outlook}

The Anthropocene concept sensu lato is still novel and fluid in the sense that it is attracting a very wide array of different approaches from scholars of both sciences and humanities, who are using it as a springboard to explore new metaphorical, philosophical, didactic, narrative and artistic approaches. Much of this discourse on the Anthropocene - in part expressed as controversy - derives from this open and "adoptive" character of the concept. It has been variously adopted or rejected for a range of purposes that include the idealistic and ideological. In order to minimise misunderstanding of what we regard as the core of the concept, which is rooted in Earth process and history, we here briefly attempt to deconstruct, and reassemble, a few different aspects of the Anthropocene:

Thus, the Anthropocene concept in effect emerged - at least in its reappearance at the beginning of the 21st century (see Hamilton \& Grinevald 2015) from the analysis of the many, mutually interacting changes in state of the present Earth System components: hence, from the Earth System sciences.

Geologists were challenged to test whether such system changes have significant geological expression in the stratigraphic record, in part via an invitation to 
establish the Anthropocene Working group by the Subcommission of Quaternary Stratigraphy, part of the International Commission on Stratigraphy. The Science paper by Waters et al. (2016), in collating and reviewing all available studies, identified seven types of signature and concluded that formal chronostratigraphical and geochronological establishment of a new geological series/epoch is not only defensible, but would also be appropriate and geologically useful. The term enables wide and effective communication of the Anthropocene concept and of its material expression in sediments and ice, but currently suffers from a wide interpretation of its meaning. By providing a precise definition of the term, it would allow a consistency in its usage, and by becoming part of the International Chronostratigraphic Chart would stabilize its meaning both within and outside the geoscience community.

The direct scientific outcomes of characterising the Anthropocene include the recognition of geological signals as additional data and proxies for ESS, especially for testing models and forecasting future scenarios. Geologists in turn benefit from this mutual exchange with the ESS, as it enables better process models of the stratigraphical data. Further, scholars of the humanities (including historians, philosophers, anthropologists, archaeologists, political scientists and artists) are able to correlate their findings and insights with the Earth history timescale. Hence, not only space, but also time is better scalable, correlateable, measurable - and indeed disputable. In wider society, geological timescales are often used as reasons for non-action on societal, intragenerational and individual timescales („climate has always changed“, „coral reefs became extinct several times, but reappeared“, and so on: cf. Leinfelder 2013, 2015). The Anthropocene helps examine whether such quoted reasons are justifiable by placing ongoing global change within a deep time context.

In addition, a clearly defined Anthropocene concept enables truly novel approaches to transdisciplinary thinking in general. In challenging well established dualistic boundaries such as nature and culture or good and bad, it can clearly help new integrative views and forms of problem-solving to emerge. 
There may even be practical benefit in helping steer towards a change from the current dysfunctionality of the combined human/planetary system to something more closely resembling a functioning and stable Anthropocene state.

In this, the Anthropocene used as metaphor might help trigger new normative and ethical thinking. If humanity now has the power of being a "geological force“, then it follows that such power should be used carefully and sparingly. Furthermore, it suggests that for human wellbeing - and survival - the whole Earth System has to be functional not just for humans, but sufficiently to maintain a biological diversity of which humans are simply part. This might be held to represent an anthropocenic imperative. Such ethical implications then may stimulate transformational thinking, to enable us to better integrate into the Earth System. That, at least, might enable the Anthropocene to symbolize hope rather than despair, and enable a practical and reflective response to the geological transformations under way, as the Earth evolves towards a novel state with no precedent on this, or any other planet that we are aware of.

Acknowledgements: Colin Waters publishes with the permission of the Executive Director, British Geological Survey, Natural Environment Research Council, and is funded by the British Geological Survey's Engineering Geology programme.

\section{References}

Barnosky AD (2008) Megafauna biomass tradeoff as a driver of Quaternary and future extinctions. Proceedings of the National Academy of Science, U.S.A 105, suppl. 1: 11543-11548.

Barnosky AD, Matzke N, Tomiya S, Wogan GOU, Swartz B, Quental TB, Marshall C, McGuire JL, Lindsey EL, Maguire KC, Mersey B and Ferrer EA (2011) Has the Earth's sixth mass extinction already arrived? Nature 471: 51-57. 
Barnosky, AD, Holmes, M, Kirchholtes, R, Lindsey, EL, McGuire, JL, Poust, AW, Stegner MA, Sunseri J, Swartz B, Swift J, Villavicencio NA and Wogan GOU (2014) Prelude to the Anthropocene: Two new North American Land Mammal Ages (NALMAs). The Anthropocene Review 1(3): 225-242.

Behrensmeyer AK (2001) Taphonomy: 3.3.7. Terrestrial Vertebrates. In: Briggs DEG and Crowther PR (eds) Palaeobiology II: 318-321.

Caldeira K and Wickett ME (2003) Anthropogenic carbon and ocean pH. Nature 425: 365 .

Canfield DE, Glazer AN and Falkowski PG (2010) The evolution and future of Earth's nitrogen cycle. Science 330: 192-196.

Catuneanu 0 (2006) Principles of Sequence Stratigraphy. 375 pp. Amsterdam: Elsevier.

Ceballos G, Ehrlich PR, Barnosky AD, García A, Pringle RM and Palmer TM (2015) Accelerated modern human-induced species losses: Entering the sixth mass extinction. Science Advances 1: e1400253.

Crutzen PJ (2002) Geology of mankind. Nature 415: 23.

Crutzen PJ and Stoermer EF (2000). The 'Anthropocene'. Global Change Newsletter 41: 17-18.

Diaz RJ and Rosenberg R (2008). Spreading dead zones and consequences for marine ecosystems. Science 321: 926-929.

Doney SC, Fabry VJ, Feely RA and Kleypas JA (2009) Ocean Acidification: The Other $\mathrm{CO}_{2}$ Problem. Annual Review of Marine Science 1: 169-192, doi:

10.1146/annurev.marine.010908.163834 
Doughty CE (2013) Preindustrial Human Impacts on Global and Regional Environment. Annual Review of Environment and Resources 38: 2.1-2.25.

Ellis EC (2011) Anthropogenic transformation of the terrestrial biosphere. Philosophical Transactions of the Royal Society, London Series A 369: 1010-1035.

Ellis EC, Antill EC and Kreft H (2012) All Is Not Loss: Plant Biodiversity in the Anthropocene. PLoS ONE 7(1): e30535. doi:10.1371/journal.pone.0030535.

Filippelli G (2002). The global phosphorus cycle. Reviews in Mineralogy and Geochemistry 48: 391-425.

Finney SC (2014). The 'Anthropocene' as a ratified unit in the ICS International Chronostratigraphic Chart: fundamental issues that must be addressed by the Task Group. In: Waters CN, Zalasiewicz J, Williams M, Ellis MA and Snelling A (eds) A Stratigraphical Basis for the Anthropocene. Geological Society, London, Special Publications 395: 23-28.

Finney SC and Edwards LE (2016) The "Anthropocene" epoch: Scientific decision or political statement? GSA Today 26 (3-4): 4-10.

Gałuszka A, Migaszewski ZM and Zalasiewicz J (2014) Assessing the Anthropocene with geochemical methods. In: Waters CN, Zalasiewicz J, Williams M, Ellis MA and Snelling A (eds) A Stratigraphical Basis for the Anthropocene. Geological Society, London, Special Publications 395: 221-238.

Gattuso JP, Smith SV, Hogan CM and Duffy JE (2009) Coastal zone. In: Cleveland CJ (ed) Encyclopedia of Earth. Environmental Information Coalition, National Council for Science and the Environment, Washington, DC. (First published in the Encyclopedia of Earth, see http://www.eoearth. org/article/Coastal_zone). 
Gibbard PL and Walker MJC (2014) The term 'Anthropocene' in the context of formal geological classification. In: Waters CN, Zalasiewicz J, Williams M, Ellis MA and Snelling A (eds) A Stratigraphical Basis for the Anthropocene. Geological Society, London, Special Publications 395: 29-37.

Hoegh-Guldberg O, Mumby PJ , Hooten AJ , Steneck, RS, Greenfield P, Gomez E, Harvell CD, Sale PF, Edwards AJ, Caldeira K, Knowlton N, Eakin CM, IglesiasPrieto R, Muthiga N, Bradbury RH, Dubi A and Hatziolos ME (2007) Coral reefs under rapid climate change and ocean acidification. Science 318/5857: 17371742, doi: 10.1126/science.1152509

Haq BU, Hardenbohl J, Vail PR and Ehrlich RN (1987) Chronology of fluctuating sea levels since the Triassic. Science 235: 1156-1166.

Hamilton C and Grinevald J (2015) Was the Anthropocene anticipated? The Anthropocene Review 2: 59-72.

Harvey MC, Brassell SC, Belcher CM and Montanari A (2008) Combustion of fossil organic matter at the Cretaceous-Paleogene (K-P) boundary. Geology 36: 355358.

Haywood AM, Dolan AM, Pickering SJ, Dowsett HJ, McClymont EL, Prescott CL, Salzmann U, Hill DJ, Hunter SJ, Lunt DJ, Pope JO and Valdes PJ (2013) On the identification of a Pliocene time slice for data-model comparison, Philosophical Transactions of the Royal Society A: Mathematical, Physical and Engineering Sciences, 371: 20120515. doi: 10.1098/rsta.2012.0515

Holtgrieve GW, Schindler DE, Hobbs WO, Leavitt PR, Ward EJ, Bunting L, Chen G, Finney BP, Gregory-Eaves I, Holmgren S, Lisac MJ, Lisi PJ, Nydick K, Rogers LA, Saros JE, Selbie DT, Shapley MD, Walsh PB and Wolfe AP (2011) A coherent 
signature of anthropogenic nitrogen deposition to remote watersheds of the Northern Hemisphere. Science 334: 1545-1548.

IPCC, Climate Change (2013) The Physical Science Basis. Contribution of Working Group I to the Fifth Assessment Report of the Intergovernmental Panel on Climate Change, Stocker TF et al., (eds) (Cambridge Univ. Press).

Kidwell SM (2015) Biology in the Anthropocene: Challenges and insights from young fossil records. Proceedings of the National Academy of Science, U.S.A. 112: 4922-4929.

Kramer N, Wohl EE and Harry DL (2012) Using ground penetrating radar to 'unearth' buried beaver dams. Geology 40: 43-46.

Koch PL and Barnosky AD (2006) Late Quaternary extinctions: State of the debate. Annual Review of Ecology, Evolution, and Systematics 37: 215-250.

Lawrence KT, Herbert TD, Dekens PS, Ravelo AC (2007) The application of the alkenone organic proxy to the study of Plio-Pleistocene climate. In: Williams M, Haywood A, Gregory FJ and Schmidt DN (eds). Deep-Time Perspectives on Climate Change: Marrying the Signal from Computer Models and Biological Proxies. The Micropalaeontological Society, The Geological Society, London, (Special Publication), pp. 539-562.

Leinfelder R. (2013) Assuming Responsibility for the Anthropocene: Challenges and Opportunities in Education. In: Trischler H (ed), Anthropocene - Envisioning the Future of the Age of Humans, RCC-Perspectives, 2/2013, 9-18, Rachel Carson Center, Munich. (doi: 10.13140/RG.2.1.2510.6968)

Leinfelder R (2015) Even the Future Was Better Back Then - New Challenges for Science and Communication. In: Möllers N, Schwägerl C and Trischler H (eds). Welcome to the Anthropocene. The Earth in Our Hands: 97-102, Deutsches Museum Verlag, München, ISBN 978-3-940396-49-5. 
Lenton T( 2016). Earth System Science: A Very Short Introduction. Oxford University Press.

Martín J, Puig P, Palanques A and Giamportone, A (2015) Commercial bottom trawling as a driver of sediment dynamics and deep Seascape evolution in the Anthropocene. Anthropocene, : 1-15. http://dx.doi.org/10.1016/j.ancene.2015.01.002

Mora C, Tittensor DP, Adl S et al. (2011) How many species are there on Earth and in the ocean? PLoS Biol 9: e1001127. doi:10.1371/journal.pbio.1001127.

Oldfield F (2015) Can the magnetic signatures from inorganic fly ash be used to mark the onset of the Anthropocene? Anthropocene Review 2: 3-13.

Orr JC et al. (2005) Anthropogenic ocean acidification over the twenty-first century and its impact on calcifying organisms. Nature 437: 681-686.

Pimm SL et al. (2014). The biodiversity of species and their rates of extinction, distribution and protection. Science 344: 1246752.

Paull CK, Ussler III W, Mitts PJ, Caress DW, West GJ (2006) Discordant ${ }^{14}$ Cstratigraphies in upper Monterey Canyon: A signal of anthropogenic disturbance. Marine Geology 233: 21-36. doi: 10.1016/j.margeo.2006.07.008

Puig P, Canals M, Company JB, Martin J, Amblas D, Lastras G, Palanques A and Calafat AM (2012) Ploughing the deep sea floor. Nature 489: 286-289.

Ramirez-Llodra E, Tyler PA, Baker MC, Bergstad OA, Clark MR, Escobar E, Levin LA, Menot L, Rowden AA, Smith CR and Van Dover CL (2011) Man and the last great wilderness: human impact on the deep sea. PLoS ONE 6: e22588. (doi:10.1371/journal. pone.0022588). 
Rathje W and Murphy C (2001) Rubbish! The Archaeology of Garbage. The University of Arizona Press, 263 pp.

Rockström J, Steffen W, Noone K, Persson Å, Chapin III FS, Lambin EF, Lenton TM, Scheffer M, Folke C, Schellnhuber HJ, Nykvist B, de Wit CA, Hughes T, van der Leeuw S, Rodhe H, Sörlin S, Snyder PK, Costanza R, Svedin U, Falkenmark M, Karlberg L, Corell RW, Fabry VJ, Hansen J, Walker B, Liverman D, Richardson K, Crutzen P and Foley JA (2009) A safe operating space for humanity. Nature 461: 472-475.

Rose NL (2015) Spheroidal carbonaceous fly ash particles provide a globally synchronous stratigraphic marker for the Anthropocene. Environmental Science and Technology 49: 4155-4162.

Ruddiman WF (2003). The anthropogenic greenhouse era began thousands of years ago. Climatic Change 61: 261-293 doi:10.1023/B:CLIM.0000004577.17928.fa

Ruddiman WF (2013). The Anthropocene. Annual Review of Earth and Planetary Sciences 41: 45-68. doi:10.1146/annurev-earth-050212-123944

Ruddiman WF, Ellis EC, Kaplan JO, Fuller DQ (2015) Defining the epoch we live in. Science $348,38-39$.

Schellnhuber HJ (1999) 'Earth System' analysis and the second Copernican revolution. Nature 402: C19-C23.

Scott AC and Glasspool IJ (2006) The diversification of Palaeozoic fire systems and fluctuations in atmospheric oxygen concentration. Proceedings of the National Academy of Science, U.S.A 103: 10861-10865.

Smil V (2011). Harvesting the biosphere: The human impact. Population and Development Review 37: 613-636. 
Steffen W, Sanderson A., Tyson, PD, Jäger J., Matson P, Moore III B, Oldfield F, Richardson K., Schellnhuber H-J, Turner II BL and Wasson RJ (2004). Global Change and the Earth System: A Planet Under Pressure. The IGBP Book Series, Springer-Verlag, Berlin, Heidelberg, New York, 336 pp.

Steffen W, Crutzen PJ and McNeill JR (2007) The Anthropocene: Are humans now overwhelming the great forces of Nature? Ambio 36: 614-621.

Steffen W, Broadgate W, Deutsch L, Gaffney O and Ludwig C (2015a) The trajectory of the Anthropocene: The Great Acceleration. The Anthropocene Review 2(1) 81-98. doi: 10.1177/2053019614564785.

Steffen W, Richardson K, Rockström J, Cornell SE, Fetzer I, Bennett EM, Biggs R, Carpenter SR, de Vries W, de Wit CA, Folke C, Gerten D, Heinke J, Mace GM, Persson LM, Ramanathan V, Reyers B and Sörlin S (2015b) Planetary Boundaries: Guiding human development on a changing planet. Science 347: doi: 10.1126/science.1259855

Swindles GT, Watson E, Turner TE, Galloway JM, Hadlari T, Wheeler J and Bacon KL (2015) Spheroidal carbonaceous particles are a defining stratigraphic marker for the Anthropocene. Scientific Reports 5: 10264.

Vajda V and McLoughlin S 2004. Fungal proliferation at the Cretaceous-Tertiary boundary. Science 3031489.

Walker MJC, Gibbard PL and Lowe J (2015) Comment on "When did the Anthropocene begin? A mid-twentieth century boundary is stratigraphically optimal" by Jan Zalasiewicz et al. (2015). Quaternary International 383: 204-207, doi: 10.1016/j.quaint.2015.04.007. 
Waters CN, Zalasiewicz JA, Williams M, Ellis MA and Snelling AM (eds) (2014) A Stratigraphical basis for the Anthropocene. Geological Society, London, Special Publication, 395.

Waters CN, Syvitski JPM, Gałuszka A, Hancock GJ, Zalasiewicz J, Cearreta A, Grinevald J., McNeill JR, Summerhayes C and Barnosky A (2015) Can nuclear weapons fallout mark the beginning of the Anthropocene Epoch? Bulletin of the Atomic Scientists 71(3): 46-57.

Waters CN, Zalasiewicz J, Summerhayes C, Barnosky AD, Poirier C, Gałuszka A, Cearreta A, Edgeworth M, Ellis EC, Ellis M, Jeandel C, Leinfelder R, McNeill JR, Richter D deB, Steffen W, Syvitski J, Vidas D, Wagreich M, Williams M, An Zhisheng, Grinevald J, Odada E, Oreskes N and Wolfe AP (2016) The Anthropocene is functionally and stratigraphically distinct from the Holocene. Science 351 issue 6269, 137.

Wilgus CK, Hastings BS, Posamentier H, Van Wagoner Y, Ross CA and Kendall CG (eds.) (1988) Sea-level changes: an integrated approach. Soc. Econ. Paleont. Mineral., Spec. Publ., 42, Tulsa.

Williams M, Zalasiewicz J, Haywood A, et al. (2011). The Anthropocene: A new epoch of geological time? Philosophical Transactions of the Royal Society 369A (1938): 833-1112.

Williams M, Zalasiewicz J, Davies N, Mazzini I, Goiran J-P and Kane S (2014) Humans as the third evolutionary stage of biosphere engineering of Rivers. Anthropocene 7: 57-63.

Williams M, Zalasiewicz JA, Haff PK, Schwägerl C, Barnosky AD and Ellis EC (2015) The Anthropocene biosphere. Anthropocene Review 2, 196-219.

Wolfe AP, Hobbs WO, Birks HH, Briner JP, Holmgren SU, Ingólfsson Ó, Kaushal SS, Miller GH, Pagani M, Saros JE and Vinebrooke RD (2013) Stratigraphic 
expressions of the Holocene-Anthropocene transition revealed in sediments from remote lakes. Earth Science Reviews 116: 17-34.

Zalasiewicz J (2008) The Earth After Us. Oxford University Press, 251 pp.

Zalasiewicz, J, Waters, CN and Williams, M. (2014a) Human bioturbation, and the subterranean landscape of the Anthropocene. Anthropocene 6:3-9.

Zalasiewicz J and Williams M (2014) The Anthropocene: a comparison with the Ordovician-Silurian boundary. Rendiconti Lincei - Scienze Fisiche e Naturali 25: $5-12$.

Zalasiewicz J and Williams M (2012) The Goldilocks Planet: An Earth History of Climate Change. Oxford University Press. 303 pp.

Zalasiewicz J and Williams M (2016) Climate change through Earth's history. In: Letcher TM (ed.) Climate Change: Observed Impacts on Planet Earth. Elsevier, pp. 3-17.

Zalasiewicz J, Williams M, Smith A, Barry TL, Coe AL, Bown PR, Brenchley P, Cantrill D, Gale A., Gibbard P, Gregory FJ, Hounslow, MW, Kerr AC, Pearson P, Knox R, Powell JH, Waters CN, Marshall J, Oates M, Rawson P and Stone P (2008) Are we living in the Anthropocene? GSA Today 18/2: 4-8.

Zalasiewicz J, Williams M and Waters CN (2014b) Can an Anthropocene Series be defined and recognized? In: Waters CN, Zalasiewicz J, Williams M, Ellis MA and Snelling A (eds) A Stratigraphical Basis for the Anthropocene. Geological Society, London, Special Publications 395: 39-54.

Zalasiewicz J, Waters CN, Williams M, Barnosky AD, Cearreta A, Crutzen P, Ellis E, Ellis MA, Fairchild IJ, Grinevald J, Haff PK, Hajdas I, Leinfelder R, McNeill JR, Odada EO, Poirier C, Richter D, Steffen W, Summerhayes C, Syvitski JPM, Vidas D, Wagreich M, Wing SL, Wolfe AP, Zhisheng An, Oreskes N (2015) When did the 
Anthropocene begin? A mid-twentieth century boundary level is stratigraphically optimal. Quaternary International 383: 196-203.

Zeebe RE and Zachos JC (2007) Reversed deep-sea carbonate ion basin gradient during Paleocene-Eocene thermal maximum. Palaeoceanography 22: PA3201, doi:10.1029/2006PA001395. 